\title{
Total Anomalous Pulmonary Venous Drainage
}

\section{A Clinical and Anatomical Study of 75 Children}

\author{
R. E. BONHAM CARTER, MIGUEL CAPRILES,^ AND YVONNE NOE† \\ From the Thoracic Unit, The Hospital for Sick Children, Great Ormond Street, London W.C.I
}

Seventy-five children with total anomalous pulmonary venous drainage have been seen at The Hospital for Sick Children, Great Ormond Street, London. Of these, 61 were proved to have this malformation at necropsy and 14 by cardiac catheterization, angiocardiography, and operation. The classification of Darling, Rothney, and Craig (1957) according to the site of drainage is used, i.e. supracardiac, cardiac, infracardiac, and mixed.

For convenience of presentation, but not as a classification, the 75 children may be divided into 2 groups. Those who were uncomplicated by other major cardiac defects numbered 58 (Group I), and those who had major additional cardiac defects numbered 17 (Group II). Group II may again be divided: Group IIa, those who had asplenia, or gross abnormalities of the spleen; and Group IIb in whom the spleen was normal. The presence of a secundum atrial septal defect is not considered as a major additional cardiac defect for the purpose of this grouping, for its presence is beneficial to the circulation.

\section{LIFE EXPECTANCY}

Fig. 1 shows the age at death or operation in all these 75 children. Fig. 2 shows the same data in Group I, and Fig. 3 the data in Group II. Of the total, 80 per cent died, or had to be operated upon before the age of 1 year. Even in the uncomplicated Group I, only 25 per cent survived infancy. Further, all those presenting as neonates died, amounting to 15 per cent of Group I. All those in Group

Received May 1, 1968.

* British Council Fellow, Avenue los Mangos, Qta. San Francisco, Urb, La Florida, Caracas, Venezuela.

$\dagger$ Academisch Ziekenhuis, Department of Pediatric Cardiology, Leiden, Holland.

$¥$ The terms used here denoting age are those of the Registrar General. That is, an infant is a baby less than 1 year old, and a neonate is a baby less than 1 month old.
II died before the age of 1 year, 90 per cent before the age of 6 months, and nearly half of them as neonates.

These figures emphasize the conclusion of Burroughs and Edwards (1960) that this lesion carries a high mortality in the first year of life. Since Muller (1951) first successfully corrected this condition by operation, improved surgical techniques and the ability to use heart-lung bypass operations in infants (Cooley and Ochsner, 1957; Cooley, Hallman, and Leachman, 1966; Bahnson, Spencer, and Neill, 1958; Guntheroth, Nadas, and Gross, 1958; Mustard, Keith, and Trusler, 1962) have made it imperative that early diagnosis of this condition be made. Unfortunately, the signs and symptoms are not such that early diagnosis by clinical methods alone is easy.

\section{Clinical Features}

The age at onset of symptoms is shown in Fig. 4 and 5, respectively. In Group I, 50 per cent had symptoms as neonates, and 90 per cent before the age of 1 year. In Group II, 80 per cent had symptoms as neonates and all of them before the age of 6 months. These symptoms do not differ from those of other babies with congenital heart disease. They are breathlessness and failure to thrive. It is, however, true that both breathlessness and failure to thrive are observations, the former, particularly, often going unobserved. It should be regarded as a sign and be seen when the infant is feeding.

Analysis of the physical findings in both groups shows the difficulty of clinical diagnosis in the infant. These signs are set out in order of their observed frequency in Fig. 6 and 7. It is important to record that the cyanosis in Group I was always slight, and was frequently unnoticed by the parents. In 30 per cent of Group I, no significant ejection murmur was heard. Further, fixed splitting of the pulmonary second sound was not noted in 25 per 


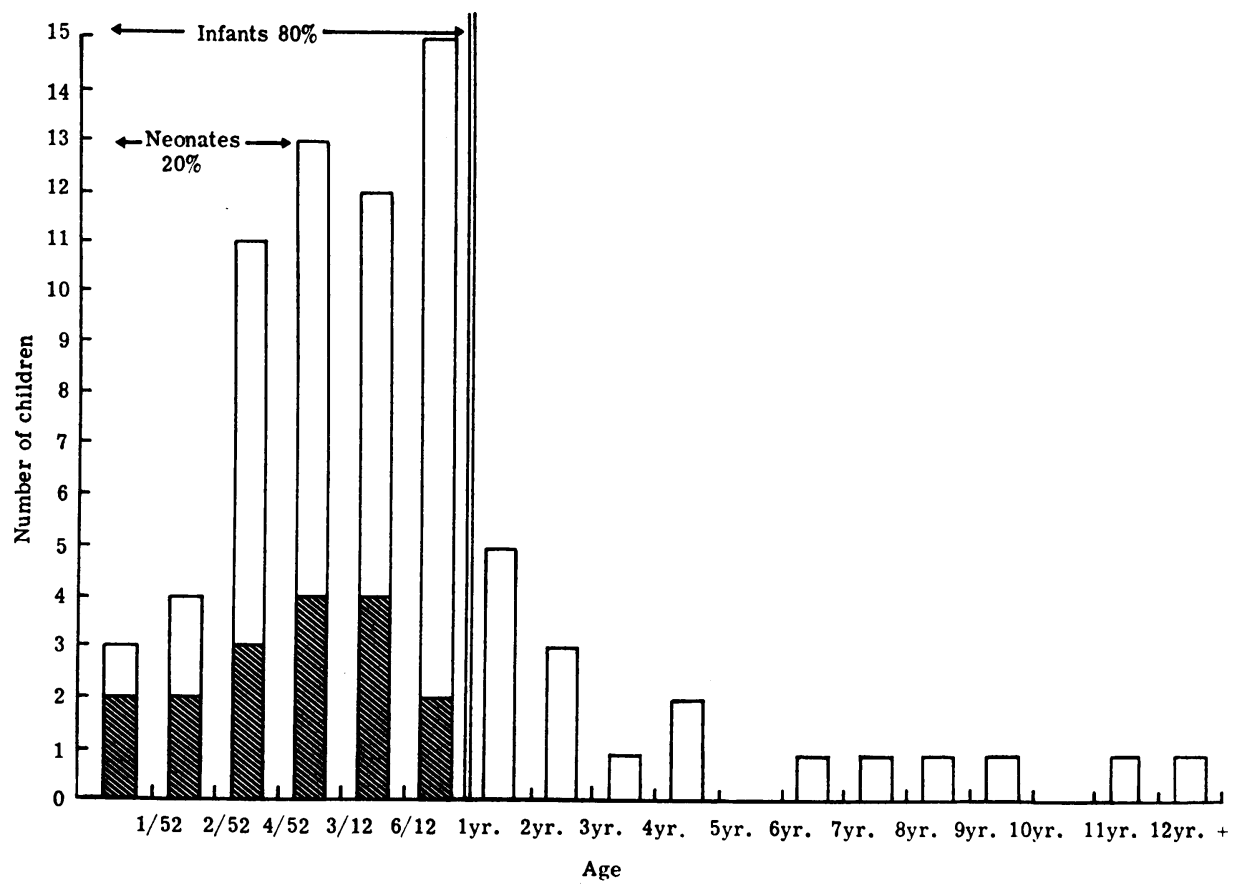

FIG. 1.-Age at death or operation in all 75 children (36 male, 39 female). $\square$ Group I. $\square$ Group II.

cent. Even cardiac enlargement was clinically detected in only 40 per cent, though some evidence of cardiac failure was present in 60 per cent. In addition to emphasizing the difficulty of clinical diagnosis, this also emphasizes the importance of radiological confirmation of heart size. These infants' hearts are always enlarged, except when there is obstruction to the pulmonary venous inflow,

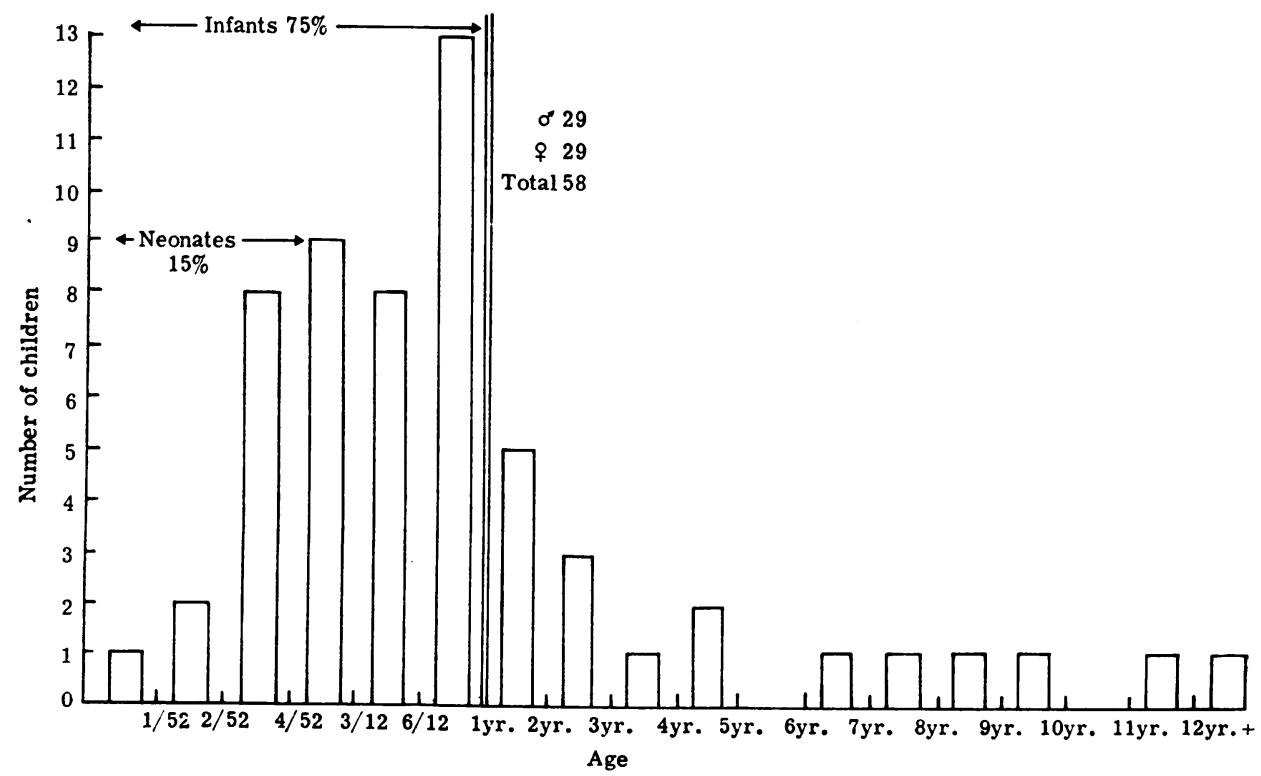

FIG. 2.-Age at death or operation in the 58 children in Group I. 


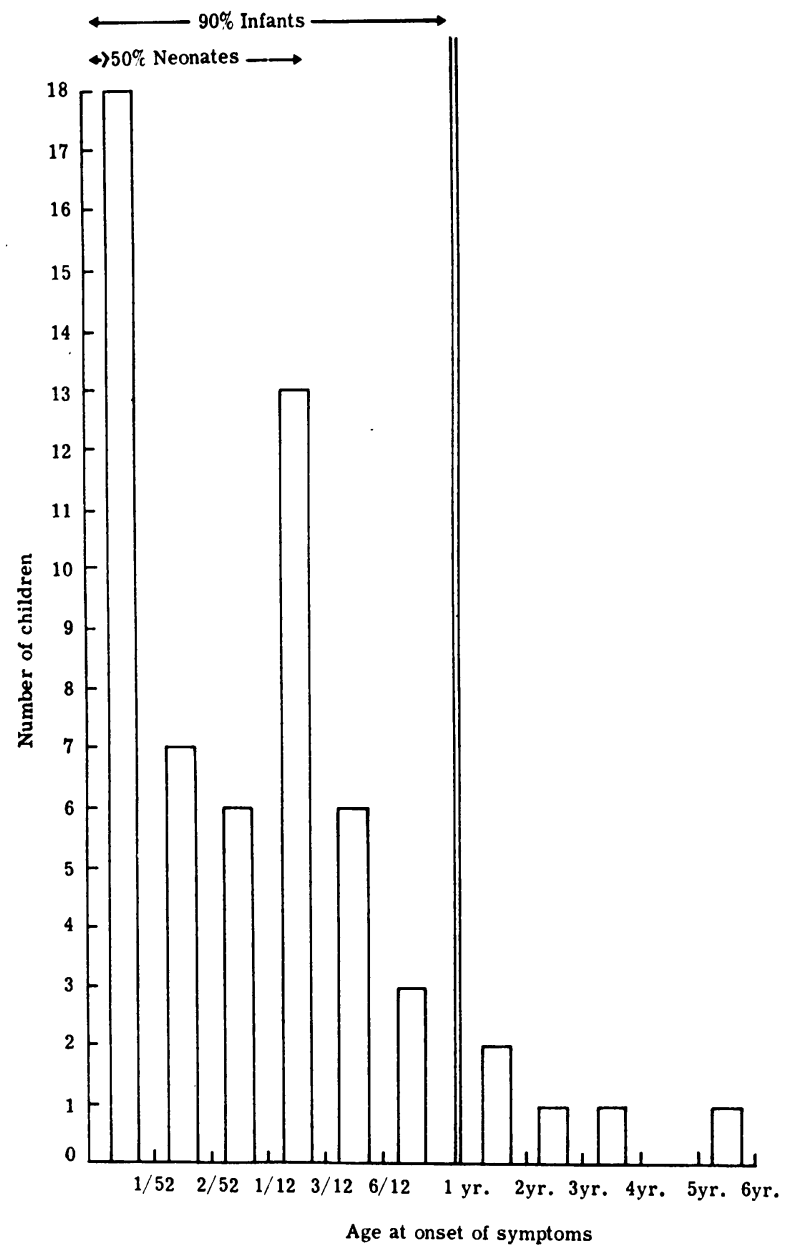

FIg. 4.-Age at onset of symptoms in children in Group I.

but they are not very big. Thus, the triad of cyanosis, clinical cardiac enlargement, and fixed splitting of the pulmonary second sound, which in an older age-group forms a basis for the suspicion of this diagnosis, is frequently not seen, and, since this is a disease presenting most commonly in infancy, the clinician is left with the need to investigate all infants with cyanosis, however slight, who have radiological evidence of cardiac enlargement, and any evidence of congestive cardiac failure or of pulmonary oedema.

Though there are differences in the signs between Group I and Group II, these are not such as will help to distinguish between the complicated and uncomplicated forms. However, in Group II cyanosis was commonly more intense, and fixed splitting of the pulmonary second sound was rarely observed.

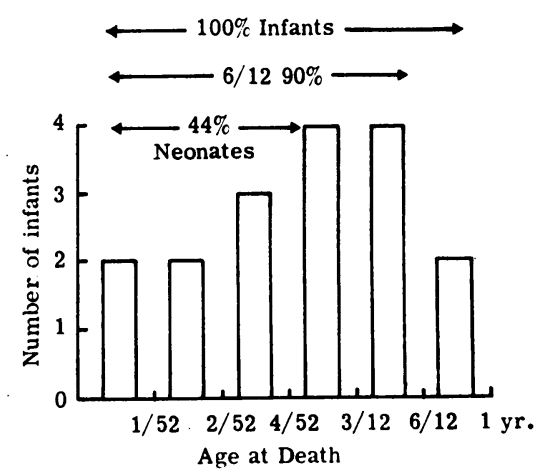

FIG. 3.-Age at death in the 17 children in Group II.

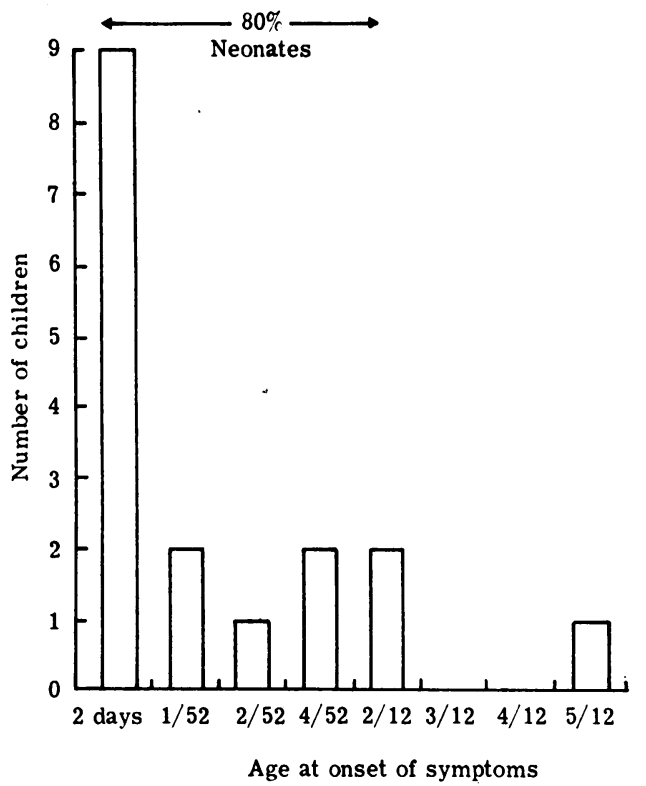

FIG. 5.-Age at onset of symptoms in children in Group II.

The presence of a continuous murmur, even when this is heard in the 2nd left interspace, does not always indicate the presence of a patent ductus arteriosus, for as Venables, Campbell, and Westlake (1964) showed, this noise may be associated with an obstructed venous return, and the commonest site for this is between the pulmonary artery and the left main bronchus (Table I). This occurred in 2 patients, producing a continuous murmur in the pulmonary area.

\section{ELECTROCARDIOGRAPHY}

An analysis of 51 electrocardiograms shows that all had normal rhythm except one child who had 


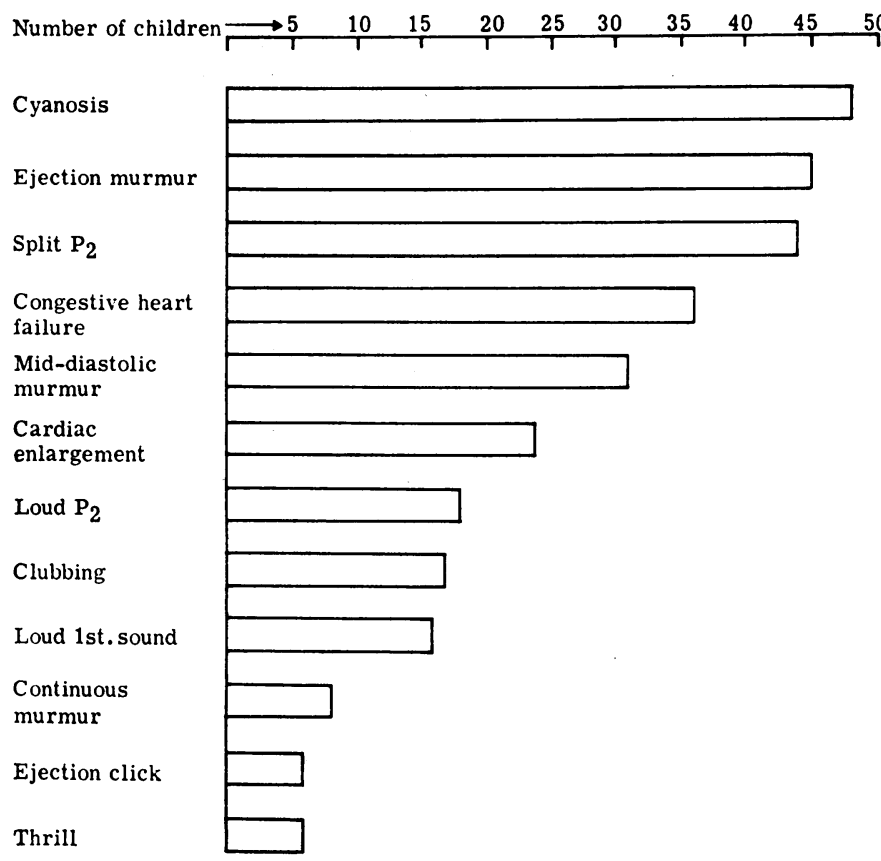

FIG. 6.-Physical findings in children in Group I.

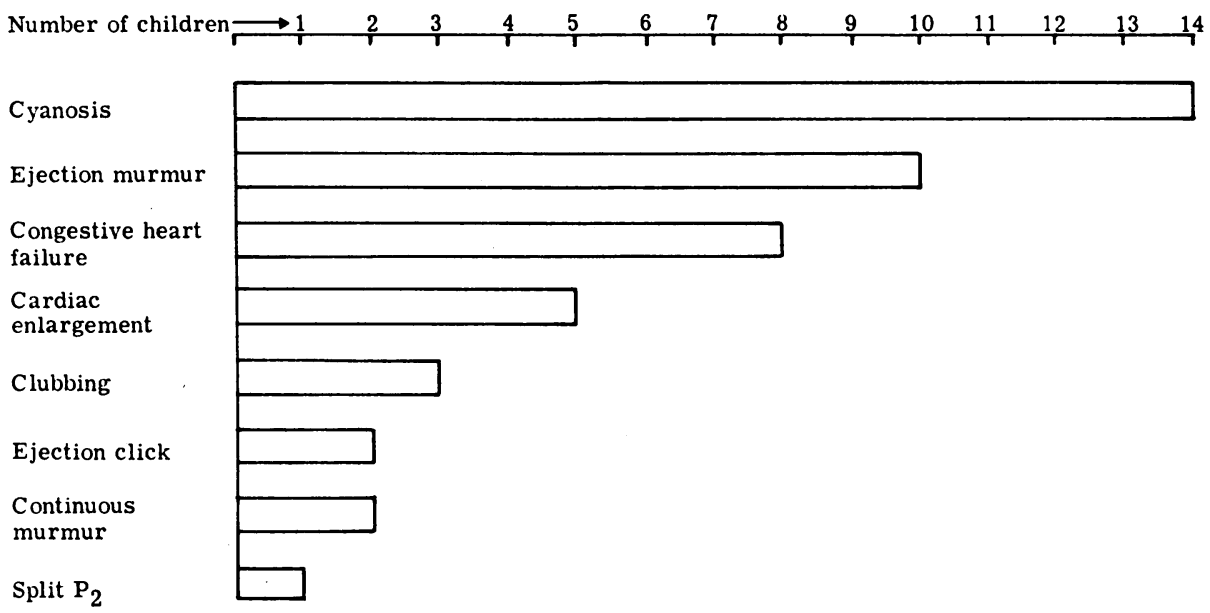

FIG. 7.-Physical findings in children in Group II.

nodal rhythm. Considering that the majority were digitalized, all had normal P-R intervals, and the length of the QRS complex was also normal. Incomplete right bundle-branch block was present in 25 per cent. Nine patients between the ages of 4 months and 12 years had electrocardiograms indistinguishable from those of uncomplicated secundum atrial septal defects, and in these the pulmonary artery pressure was measured and was found to be normal or nearly so, and there was good electrical activity over the left praecordial leads. In 5 in whom the pulmonary arterial pressure was at systemic level or higher, the electrical activity over the left praecordial leads was small or absent.

It follows that when this condition is suspected, and absent or minimal electrical activity is found over the left praecordial leads, significant pulmonary hypertension may be found, and in those with 
TABLE I

COMPRESSION OF COMMON VENOUS TRUNK (GROUP I UNCOMPLICATED)

\begin{tabular}{l|c}
\hline \multicolumn{1}{c|}{ Site } & No. \\
\hline Left main bronchus and pulmonary artery & 5 \\
In the liver or below & 3 \\
By fibrous band (intrapulmonary trunk) & 1 \\
Narrow left innominate & 1 \\
Narrow opening into right superior vena cava & 1 \\
\hline Total & 11 \\
\hline
\end{tabular}

electrocardiograms like those of secundum atrial septal defect, normal or only flow raised pulmonary artery pressures will be found. This finding leads to speculation about the effect of the size of the atrial septal defect upon the development of the left heart. We have not been able to measure left heart cavity size in these sick infants; all that can be said is that in those 3 with probe patent foramina ovale, the left heart chambers were very small at necropsy.

\section{Chest Radiograph}

Initially, chest films have shown a heart of normal or slightly increased size. Conspicuous cardiac dilatation sometimes occurred as the infant approached the terminal stage of his illness. Generally, the superior mediastinal configuration was unremarkable. Even in those infants in whom the common pulmonary venous trunk passed to the left innominate vein, there was little or no superior mediastinal widening. The "snowman" or "cottage loaf" appearance, seen in older patients with anomalous pulmonary venous drainage of this type, was very rarely seen in infants, the youngest being 8 months of age. Where there was no obstruction to flow through the common anomalous pulmonary venous trunk, the pulmonary vessels were increased in size. Pulmonary oedema was seen when there was obstruction to pulmonary venous drainage. Both frontal and lateral chest projections have been found useful. The signs of pulmonary oedema were as follows: (i) perihilar shadowing obscured the hilar vessel shadows and resulted in an air bronchogram effect; (ii) peribronchial "cuffing" was seen; (iii) in the otherwise clear periphery of the lung, septal lines could be noted in the retrosternal region and less commonly in the costophrenic angles; (iv) lung fissure shadows were prominent. Intra-alveolar oedema is predominantly responsible for (i). Interstitial oedema and dilated lymphatics largely account for (ii), (iii), and (iv). Diaphragmatic flattening and sternal bowing is seen and is probably due to decrease in lung compliance.

\section{Drainage of Pulmonary Veins}

Tables II, III, and IV show the anatomical drainage of the pulmonary veins in Groups I, IIa, and IIb, respectively. Of the 58 uncomplicated ones in Group I, 51 had supracardiac or cardiac drainage. There were only 5 complete infracardiac connexions.

TABLE II

DRAINAGE OF PULMONARY VEINS (GROUP I UNCOMPLICATED)

\begin{tabular}{|c|c|c|c|}
\hline \multirow{3}{*}{$\begin{array}{l}\text { Left superior vena cava via innominate } \\
\text { Coronary sinus } \\
\text { Right superior vena cava } \\
\text { Portal vein } \\
\text { Right atrium } \\
\text { Left hepatic vein } \\
\text { Inferior vena cava } \\
\text { Inferior vena cava and left innominate vein, } 2 \text { trunks } \\
\text { Left superior vena cava and coronary sinus, } 2 \text { trunks }\end{array}$} & \multirow{3}{*}{$\begin{array}{r}30 \\
16 \\
3 \\
3 \\
2 \\
1 \\
1 \\
1 \\
1\end{array}$} & $\begin{array}{l}\text { Complete supracardiac } \\
\text { Complete cardiac } \\
\text { Mixed cardiac and supracardiac } \\
\text { Complete infracardiac } \\
\text { Mixed supra and infracardiac }\end{array}$ & $\begin{array}{r}33 \\
18 \\
1 \\
5 \\
1\end{array}$ \\
\hline & & \multirow[t]{3}{*}{ Total } & 58 \\
\hline & & & \\
\hline Total & 58 & & \\
\hline
\end{tabular}

TABLE III DRAINAGE OF PULMONARY VEINS IN WITH ABNORMALITIES OF SPLEEN

\begin{tabular}{l|c}
\hline \multicolumn{1}{c|}{ Site } & No. \\
\hline Right superior vena cava & 3 \\
Portal vein & 3 \\
Left superior vena cava in dextrocardia & 1 \\
Azygos vein & 2 \\
Right atrium & 1 \\
\hline Total & 10 \\
\hline
\end{tabular}

TABLE IV

DRAINAGE OF PULMONARY VEINS IN DRAINAGE OF PULUP IIB WITHOUT ABNORMALITIES OF SPLEEN

\begin{tabular}{l|c}
\hline \multicolumn{1}{c|}{ Site } & No. \\
\hline Left superior vena cava (one by 2 trunks) & 3 \\
Coronary sinus & 2 \\
Right superior vena cava & 1 \\
Triatrial heart chamber & 1 \\
\hline Total & 7 \\
\hline
\end{tabular}


TABLE V

OTHER MALFORMATIONS: GROUP IIA, WITH ABNORMALITIES OF SPLEEN (TOTAL 10)

\begin{tabular}{|c|c|c|c|c|c|c|c|c|c|c|c|}
\hline Atrial & No. & Ventricular & No. & $\begin{array}{l}\text { Pulmonary } \\
\text { outflow }\end{array}$ & No. & Aortic outflow & No. & Venous & No. & Extracardiac & No \\
\hline $\begin{array}{l}\text { Single atrium } \\
\text { Ostium primum } \\
\text { Ostium secundum }\end{array}$ & $\begin{array}{l}7 \\
1 \\
1\end{array}$ & $\begin{array}{l}\text { Single ventricle } \\
\text { AV canal }\end{array}$ & $\begin{array}{l}\mathbf{5} \\
\mathbf{7}\end{array}$ & $\begin{array}{l}\text { Pulmonary } \\
\text { stenosis } \\
\text { Pulmonary } \\
\text { atrium } \\
\text { Hypoplastic } \\
\text { artery } \\
\text { Double outflow } \\
\text { right ventricle }\end{array}$ & $\begin{array}{l}4 \\
2 \\
1 \\
1\end{array}$ & $\begin{array}{c}\text { Persistent duc- } \\
\text { tus arteriosis } \\
\text { Double outflow } \\
\text { left ventricle } \\
\text { Transposition of } \\
\text { great arteries }\end{array}$ & $\begin{array}{l}4 \\
2 \\
3\end{array}$ & $\begin{array}{l}\text { Absent coron- } \\
\text { ary sinus } \\
\text { Bilateral superior } \\
\text { vena cava } \\
\text { Absent } \\
\text { innominate } \\
\text { Hepatic vein to } \\
\text { left atrium } \\
\text { Lt. sided inferior } \\
\text { vena cava } \\
\text { Lt. gastric vein } \\
\text { to pulmonary } \\
\text { trunk } \\
\text { Abnormal por- } \\
\text { tal vein } \\
\text { Inferior vena } \\
\text { cava formed } \\
\text { at level of } \\
\text { renal veins }\end{array}$ & $\begin{array}{l}8 \\
4 \\
4 \\
3 \\
2 \\
1 \\
1 \\
1\end{array}$ & $\begin{array}{l}\text { Lt. sided liver } \\
\text { Central liver } \\
\text { Universal } \\
\text { mesentery } \\
\text { Duodenal } \\
\text { stenosis } \\
\text { Absent spleen } \\
\text { Spleniculi }\end{array}$ & $\begin{array}{l}2 \\
7 \\
7 \\
1 \\
8\end{array}$ \\
\hline
\end{tabular}

TABLE VI

OTHER MALFORMATIONS: GROUP IIB, WITHOUT ABNORMALITIES OF SPLEEN (TOTAL 7)

\begin{tabular}{|c|c|c|c|c|c|c|c|c|c|c|c|}
\hline Atrial & No. & Ventricular & No. & $\begin{array}{l}\text { Pulmonary } \\
\text { outflow }\end{array}$ & No. & Aortic outflow & No. & Venous & No. & Extracardiac & No. \\
\hline $\begin{array}{l}\text { Ostium secundum } \\
\text { Probe patent fora- } \\
\text { men ovale } \\
\text { Small left atrium } \\
\text { Coronary sinus to } \\
\text { left atrium } \\
\text { probe patent } \\
\text { Mitral atresia } \\
\text { Mitral stenosis }\end{array}$ & $\begin{array}{l}3 \\
3 \\
2 \\
1 \\
1 \\
1\end{array}$ & $\begin{array}{l}\text { Ventricular sep- } \\
\text { tal defect } \\
\text { Corrected trans- } \\
\text { position in } \\
\text { dextrocardia }\end{array}$ & $\begin{array}{l}4 \\
1\end{array}$ & $\begin{array}{l}\text { Stenosis } \\
\text { subvalvar } \\
\text { Bicuspid valve }\end{array}$ & $\begin{array}{l}1 \\
2\end{array}$ & $\begin{array}{l}\text { Persistent duc- } \\
\text { tus arteriosis } \\
\text { (4 large) } \\
\text { Preductal } \\
\text { coarctation } \\
\text { Aberrant-rt. } \\
\text { subclavian } \\
\text { Rt. arch } \\
\text { Bicuspid valve } \\
\text { Innominate } \\
\text { (brachioce- } \\
\text { phalic artery) } \\
\text { Hypoplastic } \\
\text { ascending } \\
\text { aorta } \\
\text { Arch atresia }\end{array}$ & $\begin{array}{l}6 \\
2 \\
2 \\
1 \\
1 \\
1 \\
1 \\
1\end{array}$ & $\begin{array}{l}\text { Absent } \\
\text { innominate } \\
\text { Inferior vena } \\
\text { cava to left } \\
\text { atrium }\end{array}$ & $\begin{array}{l}1 \\
1\end{array}$ & $\begin{array}{l}\text { Universal } \\
\text { mesentery } \\
\text { Tracheo- } \\
\text { oesophageal } \\
\text { fistula } \\
\text { Horseshoe } \\
\text { kidney } \\
\text { Bilateral cleft- } \\
\text { lip and cleft } \\
\text { palate } \\
\text { Arthrogryposis }\end{array}$ & $\begin{array}{l}2 \\
1 \\
1 \\
1 \\
1\end{array}$ \\
\hline
\end{tabular}

The importance of this finding is that both supracardiac and cardiac connexions are surgically more easily correctable, though in the infant all may be difficult. In Group IIa, that is those with abnormalities of the spleen, 7 out of 10 had supracardiac or cardiac connexions, and in Group IIb all had supracardiac or cardiac connexions.

\section{Obstruction to Main Pulmonary Venous Trunk}

This finding is important, for, if severe, it leads to the development of pulmonary hypertension. In Group I (Table I) the commonest site of this compression of the main pulmonary venous trunk is between the left main bronchus and the pulmonary artery, where surgical relief is possible. Where the drainage is infracardiac, obstruction is the rule. A long connexion may in itself impede the venous return. The thoraco-abdominal pressure difference must also be an obstructive factor with the seesaw effect of respiration upon these pressures.
Further, when the venous trunk passes to the porta hepatis, the hepatic vascular bed presents a formidable obstruction to a large blood flow.

\section{Other Congenital Malformations}

Both intra- and extracardiac malformations are set out in Tables V and VI for Group IIa and IIb, respectively.

It will be seen that in Group IIa, variations of malformations of the atrioventricular canal are the rule rather than the exception, as are abnormalities of systemic venous drainage, including the absent coronary sinus. Outside the heart a left-sided or centrally placed liver, and universal mesentery are usual.

In contrast, AV canal defects were not found in Group IIb, where there were other major malformations of the heart, but where the spleen was normal; nor were these associated with subdiaphragmatic abnormalities. 


\section{Discussion}

Though this anomaly has been known for more than two centuries (Snellen and Dekker, 1963; Brody, 1942), it is only in the past decade that surgical correction (Muller, 1951), especially in infants (Cooley and Ochsner, 1957), has been possible. The present series has been collected largely from 1000 consecutive necropsies performed at this hospital upon children with congenital heart disease between 1951 and 1966, to which have been added 14 patients whose data were ascertained by cardiac catheter, angiocardiography, and operation. Burroughs and Edwards (1960) include data from 188 patients, 176 of these being published reports, and 12 not previously reported. There are significant differences between the present series and theirs. The ratio of major associated cardiac malformations is lower in the present series, 17 in 75, compared with 66 in 188. The sex incidence is also different, being equal in the present series. In their classification of long and short route drainage only one patient survived to adolescence with long route drainage; there were none in the present series who survived infancy. The formula for longevity is the same in both series, that is, a short venous connexion, the presence of a sizeable atrial septal defect larger than a patent foramen ovale, the absence of other major cardiac anomalies, and the absence of obstruction to the inflow. The present series also differs from that of Burroughs and Edwards (1960) in that atrioventricular canal defects were commonly found in this series, in those with abnormalities of the spleen. Abnormalities of systemic venous drainage were commonly found in this series in those with abnormalities of the spleen. Abnormalities of systemic venous drainage were commonly found in both series. It is probable that the collection of data from a single source will give a more accurate ratio of these factors. The relative incidence of the various sites of drainage do not materially differ between the two series. This is important, for supracardiac or cardiac drainage being common in the group uncomplicated by other major cardiac abnormalities made the majority of this group potentially operable.

The importance of the size of the atrial communication, to which Burchell (1956) drew attention, is noted in this series, and in our view relates to the ultimate outcome, for if there is an atrial septal defect larger than a foramen ovale, a bidirectional atrial shunt becomes possible, giving better systemic oxygenation and possibly better growth of the left heart, which is otherwise starved of blood. All those surviving beyond the first year of life had secundum atrial septal defects.

\section{SUMMARY}

A series of 75 children with total anomalous pulmonary venous drainage indicates that this is a disease of infancy, more than three-quarters of them dying or requiring operation before the age of 1 year. The importance and difficulty of early diagnosis are emphasized, as is the necessity of early investigation of cyanotic congenital heart disease when there is radiological evidence of cardiac enlargement, even if both cyanosis and cardiac enlargement are slight.

\section{REFERENCES}

Bahnson, H. T., Spencer, F. C., and Neill, C. A. (1958). Surgical treatment of 35 cases of drainage of pulmonary veins to the right side of the heart. $\mathscr{f}$. thorac. Surg., 36, 777.

Brody, H. (1942). Drainage of the pulmonary veins into the right side of the heart. Arch. Path., 33, 221.

Burchell, H. B. (1956). Total anomalous pulmonary venous drainage: clinical and physiologic patterns. Proc. Mayo Clin., 31, 161.

Burroughs, J. T., and Edwards, J. E. (1960). Total anomalous pulmonary venous connection (review). Amer. Heart F., 59, 913.

Cooley, D. A., Hallman, G. L., and Leachman, R. D. (1966). Total anomalous pulmonary venous drainage. $\mathcal{f}$. thorac. cardiovasc. Surg., 51, 88.

- and Ochsner, A., Jr. (1957). Correction of total anomalous pulmonary venous drainage. Surgery, 42, 1014.

Darling, R. C., Rothney, W. B., and Craig, J. M. (1957). Total pulmonary venous drainage into the right side of the heart. Lab. Invest., 6, 44.

Guntheroth, W. G., Nadas, A. S., and Gross, R. E. (1958). Transposition of the pulmonary veins. Circulation, 18, 117.

Muller, W. H., Jr. (1951). The surgical treatment of transposition of the pulmonary veins. Ann. Surg., 134, 683.

Mustard, W. T., Keith, J. D., and Trusler, C. A. (1962). Two-stage correction for total anomalous pulmonary venous drainage in childhood. $\mathcal{F}$. thorac. cardiovasc. Surg., 44, 477.

Snellen, H. A., and Dekker, A. (1963). Anomalous pulmonary venous drainage in relation to left superior vena cava and coronary sinus. Amer. Heart F., 66, 184.

Venables, A. W., Campbell, P. E., and Westlake, G. W. (1964). Total anomalous pulmonary venous drainage with unusual features. Brit. Heart F., 26, 129. 